\title{
Molecular analysis of resistance to powdery mildew (Blumeria graminis f. sp. tritici) of selected winter wheat genotypes analyzed in post-registration variety testing
}

\section{Molekularna ocena odporności na mączniaka prawdziwego zbóż i traw (Blumeria graminis f. sp. tritici) wybranych genotypów pszenicy ozimej analizowanych w doświadczeniach porejestrowych}

\author{
Justyna Szwarc*, Danuta Kurasiak-Popowska, Agnieszka Tomkowiak, Roksana Skowrońska
}

Summary

The aim of this study was to identify powdery mildew resistance genes in winter wheat cultivars obtained from Post-registration Variety Testing (PDO). The research material contained leaves of 46 winter wheat cultivars, obtained from post-registration cultivar testing field trials in Choryń, conducted by Danko Hodowla Roślin. Primers designed based on the markers Xcfd81 (Pm2 gene) and $S T S_{-241}$ (Pm4b gene) were used to identify resistance genes. $P m 2$ gene was identified in 23 cultivars and $P m 4 b$ gene was identified in 21 cultivars. This study confirmed the efficiency of $X c f d 81$ and $S T S_{-241}$ markers in identification of $P m 2$ and $P m 4 b$ genes.

Key words: wheat, $X c f d 81, S_{-241}$, powdery mildew

\section{Streszczenie}

Celem pracy była identyfikacja genów odporności na mączniaka prawdziwego zbóż i traw u odmian pszenicy zwyczajnej ozimej pochodzących z Porejestrowego Doświadczalnictwa Odmianowego (PDO). Materiał badawczy stanowiły liście 46 odmian pszenicy ozimej, pozyskane z doświadczeń PDO w Choryni prowadzonych przez Danko Hodowla Roślin. Do identyfikacji genów odporności wykorzystano startery zaprojektowane na bazie markerów Xcfd81 (gen Pm2) oraz STS ${ }_{-241}$ (gen Pm4b). Gen Pm2 zidentyfikowano u 23 odmian, a gen $P m 4 b$ zidentyfikowano u 21 odmian. Badania potwierdziły skuteczność markerów Xcfd81 oraz STS ${ }_{-241}$ w identyfikacji genów Pm2 i $P m 4 b$.

Słowa kluczowe: pszenica, $X c f d 81$, STS $_{-241}$, mączniak prawdziwy

\footnotetext{
Uniwersytet Przyrodniczy w Poznaniu

Katedra Genetyki i Hodowli Roślin

Dojazd 11, 60-632 Poznań

*corresponding author: justyna.szwarc@up.poznan.pl
} 


\section{Wstęp / Introduction}

Pszenica zwyczajna (Triticum aestivum L.) jest zbożem podatnym na wiele chorób, a za jedną z najważniejszych uznaje się mączniaka prawdziwego zbóż i traw (Jasińska i Kotecki 2003; Tratwal 2012). Sprawca choroby - Blumeria graminis f. sp. tritici może powodować straty plonu sięgające 34-50\% (Niewoehner i Leath 1998; Czajowski i Czembor 2016). Za najskuteczniejsze metody walki z mączniakiem prawdziwym zbóż i traw uważa się stosowanie fungicydów oraz hodowlę odmian odpornych (Kowalczyk i wsp. 2011). Blumeria graminis f. sp. tritici jest jednym z organizmów o wysokim ryzyku wykształcenia odporności na substancje czynne używane w fungicydach, dlatego metoda hodowlana jest przez wielu autorów uznawana za najlepszy sposób ograniczania występowania tego patogena (Ge i wsp. 1998; Kowalczyk i wsp. 2011; Czajowski i Czembor 2016). Dotychczas odkryto 77 genów odporności pszenicy $(P m)$ zlokalizowanych w 49 loci. Niektóre loci (Pm1, Pm2, Pm3, Pm4, Pm5, Pm8, Pm24) zawierają więcej niż jeden wariant genu (Miranda i wsp. 2006; Hao i wsp. 2015). Odmiany pszenicy tylko z jednym genem odporności na mączniaka prawdziwego szybko stają się podatne na patogena. Rozwiązaniem problemu przełamywania odporności jest piramidyzacja polegająca na kumulowaniu wielu genów odporności w jednym genotypie (odmianie) za pomocą hodowli (Bennett 1984; Singrün i wsp. 2004). Wiele genów odporności używanych w hodowli zostało zmapowanych za pomocą markerów molekularnych - znaczników sprzężonych z nimi cech. Selekcja z użyciem markerów (MAS - marker-assisted selection) umożliwia identyfikację genów u wprowadzanych odmian w sposób szybki, niezawodny oraz niezależny od warunków zewnętrznych i faz rozwojowych rośliny (Pietrusińska i Czembor 2015). MAS jest szczególnie przydatna w przypadku cech, które trudno ocenić poprzez obserwację roślin (Mohan i wsp. 1997). Do najczęściej stosowanych technik MAS zaliczyć można selekcję przy użyciu następujących typów markerów: Randomly Amplified Polymorphic DNA (RAPD), Restriction Fragment Length Polymorphism (RFLP), Amplified Fragment Lenght Polymorphism (AFLP), Simple Sequence Repeats (SSR), Sequence Tagged Site (STS) i Sequence Characterized Amplified Region (SCAR) (Sztuba-Solińska 2005).

Celem pracy była identyfikacja genów odporności na mączniaka prawdziwego zbóż i traw $(P m 2$ i $P m 4 b) \mathrm{u}^{-}$ mian pszenicy zwyczajnej ozimej pochodzących z Porejestrowego Doświadczalnictwa Odmianowego.

\section{Materiały i metody / Materials and methods}

Materiał badawczy stanowiły liście 46 odmian pszenicy zwyczajnej pochodzące z doświadczeń prowadzonych w 2017 roku przez firmę Danko Hodowla Roślin w ramach Porejestrowego Doświadczalnictwa Odmianowego organizowanego przez Centralny Ośrodek Badania Odmian Roślin Uprawnych (COBORU). Wszystkie odmiany oprócz Memory, Julius, Aleksander i Desamo są wpisane do Krajowego Rejestru Odmian. Wykaz odmian poddanych analizie wraz z nazwą hodowcy zachowującego odmianę został przedstawiony w tabeli 1. Izolację DNA wykonano przy użyciu zestawu do izolacji genomowego DNA z materiału roślinnego Genomic Mini AX Plant (A\&A Biotechnology), zgodnie z załączonym protokołem. Po wykonaniu izolacji zmierzono koncentrację DNA w próbach przy użyciu spektrofotometru DS-11 DeNovix. Następnie próby rozcieńczono buforem Tris $\mathrm{HCl} 10 \mathrm{mM}$ (A\&A Biotechnology) w celu uzyskania jednolitego stężenia DNA 70 ng/ $\mu$ l. Łańcuchową reakcję polimerazy (PCR - polymerase chain reaction) przeprowadzono $\mathrm{w}$ mieszaninie o składzie: woda - $5 \mu$, DreamTaq PCR MasterMix (Thermo Fisher Scientific) $-6,25 \mu 1$, startery $-2 \times 0,25 \mu 1$, matryca DNA - $1 \mu 1$. Stężenie końcowe starterów wynosiło $20 \mu \mathrm{M}$. W celu identyfikacji genów odporności pszenicy na mączniaka prawdziwego zbóż i traw wykorzystano następujące markery: Xcfd81 - identyfikacja genu $P m 2$, STS ${ }_{-241}$ - identyfikacja genu Pm4b (tab. 2). Reakcje PCR przeprowadzano w termocyklerze T3 (Biometra). Warunki reakcji były jednakowe dla identyfikowanych markerów, a profil reakcji przedstawiał się następująco: denaturacja wstępna -3 minuty $\mathrm{w} 94^{\circ} \mathrm{C}, 40$ cykli (denaturacja - 30 sekund $\mathrm{w} 94^{\circ} \mathrm{C}$, przyłączanie starterów - 1 minuta w $56^{\circ} \mathrm{C}$, synteza -1 minuta $\mathrm{w} 72^{\circ} \mathrm{C}$ ), synteza końcowa -5 minut $\mathrm{w} 72^{\circ} \mathrm{C}$. Elektroforezę prowadzono w 2,5\% żelu agarozowym, do którego dodano barwnik Midori Green Advance DNA Stain (Nippon Genetics Europe) w ilości $5 \mu 1$ na $100 \mathrm{ml}$ żelu. Rozdział wykonano pod napięciem prądu $120 \mathrm{~V}$ w warunkach chłodni przez 1,5 godziny. Do wizualizacji produktów reakcji PCR wykorzystano transiluminator GelDoc XR+ (Biorad) oraz program ImageLab (Biorad).

\section{Wyniki i dyskusja / Results and discussion}

W wyniku przeprowadzonych analiz z użyciem markera Xcfd81 zidentyfikowano gen Pm2 u 23 odmian pszenicy (rys. 1, 2, 3). Marker $S T S_{-241}$ umożliwił identyfikację genu $P m 4 b$ u 21 badanych odmian (rys. 4, 5, 6). Szczegółowa interpretacja analiz znajduje się w tabeli 3.

Zgodnie z opisową listą odmian (Bundessortenamt 2018), gen Pm2 posiadają odmiany: Patras, Tobak i Sailor. Według Tomkowiak i wsp. (2017) odmiana Hondia również posiada ten gen. W trakcie badań udało się potwierdzić te informacje, co świadczy o skuteczności markera Xcfd81. Również badania Huang i wsp. (2012) oraz Ma i wsp. (2015, 2016) potwierdzają dużą przydatność tego markera. W pracy Tomkowiak i wsp. (2017), marker umożliwił 
zidentyfikowanie genu Pm2 u 21 z 27 odmian pszenicy zawierających ten gen.

Według Bundessortenamt (2018), gen Pm4b posiadają odmiany Sailor oraz Franz. Niniejsze badania potwierdzają te informacje, co wskazuje na skuteczność markera $S T S_{-24 I}$. Według Yi i wsp. (2008), marker ten jest użyteczny i z powodzeniem może być stosowany w analizach molekularnych. W badaniach Kowalczyka i wsp. (2011) ten sam marker również umożliwił zidentyfikowanie genu $P m 4 b$. Na podstawie badań w tej pracy oraz wymienionych autorów, można stwierdzić, że marker $S T S_{-241}$ jest wysoce przydatny do identyfikacji genu Pm4b pszenicy.

Połowa spośród badanych $\mathrm{w}$ tej pracy genotypów posiada gen $P m 2$, z kolei gen $P m 4 b$ występuje u $46 \%$ analizowanych odmian. Aż $42 \%$ badanych odmian, u których skutecznie udało się zidentyfikować gen $P m 2$ lub $P m 4 b$ po-

Tabela 1. Wykaz badanych odmian wraz z listą hodowców zachowujących (COBORU 2018)

Table 1. List of studied cultivars and a list of maintainers of cultivars (breeders COBORU 2018)

\begin{tabular}{|c|c|c|c|}
\hline $\begin{array}{l}\text { Odmiana } \\
\text { Cultivar }\end{array}$ & $\begin{array}{c}\text { Hodowca zachowujący } \\
\text { Breeder }\end{array}$ & $\begin{array}{l}\text { Odmiana } \\
\text { Cultivar }\end{array}$ & $\begin{array}{c}\text { Hodowca zachowujący } \\
\text { Breeder }\end{array}$ \\
\hline 1 Belissa & HR Smolice Grupa IHAR & 24 KWS Livius & KWS Lochow GmbH \\
\hline 2 Opcja & HR Strzelce Grupa IHAR & 25 KWS Ozon & KWS Lochow GmbH \\
\hline 3 Pokusa & HR Strzelce Grupa IHAR & 26 Franz* & Nordsaat \\
\hline 4 Medalistka & Małopolska Hodowla Roślin & 27 Rivero & Nordsaat Saatzucht \\
\hline 5 Natula & Małopolska Hodowla Roślin & 28 Aleksander & Secobra Recherches \\
\hline 6 Astoria & Poznańska Hodowla Roślin & 29 Sailor* & Secobra Saatzucht GmbH \\
\hline 7 Arkadia & Danko HR & 30 Florus & Strube \\
\hline 8 Banderola & Danko HR & 31 Lavantus & Strube \\
\hline 9 Hondia & Danko HR & 32 Leandrus & Strube \\
\hline 10 Jantarka & Danko HR & 33 Platin & Strube \\
\hline 11 Mewa & Danko HR & 34 Rotax & Strube \\
\hline 12 Ostroga & Danko HR & 35 Desamo & Syngenta Seeds GmbH \\
\hline 13 Tytanika & Danko HR & 36 Dolores & Syngenta Seeds GmbH \\
\hline 14 Memory & Secobra Recherches SA & 37 Fakir & Syngenta Seeds GmbH \\
\hline 15 Bartosz & Borries-Eckendorf & 38 Delawar & Syngenta Seeds GmbH \\
\hline 16 Bonanza & Borries-Eckendorf & 39 Fidelius & Saatzucht Donau \\
\hline 17 Janosch & Borries-Eckendorf & 40 Frisky & Limagrain Europe \\
\hline 18 Tobak* & Borries-Eckendorf & 41 LG Jutta & Limagrain Europe \\
\hline 19 Artist & Deutsche Saatveredelung AG & 42 Linus & RAGT 2n \\
\hline 20 Patras* & Deutsche Saatveredelung AG & 43 Praktik & RAGT 2n \\
\hline 21 Julius & KWS Lochow GmbH & 44 RGT Kicker & RAGT 2n \\
\hline 22 KWS Dakotana & KWS Lochow GmbH & 45 RGT Kilimanjaro & RAGT 2n \\
\hline 23 KWS Kiran & KWS Lochow GmbH & 46 Hybery & Saaten Union Recherche \\
\hline
\end{tabular}

*odmiany referencyjne, o potwierdzonej obecności genów odporności na mączniaka prawdziwego zbóż i traw (Bundessortenamt 2018) reference cultivars with confirmed presence of powdery mildew resistance genes (Bundessortenamt 2018)

Tabela 2. Charakterystyka starterów wykorzystanych do łańcuchowej reakcji polimerazy (PCR)

Table 2. Characteristics of primers used in polymerase chain reaction

\begin{tabular}{c|c|c|c}
\hline $\begin{array}{c}\text { Marker } \\
\text { Marker }\end{array}$ & $\begin{array}{c}\text { Sekwencje starterów } \\
\text { Primers sequence }\end{array}$ & $\begin{array}{c}\text { Oczekiwany produkt reakcji PCR [pz] } \\
\text { Expected PCR product [bp] }\end{array}$ & $\begin{array}{c}\text { Źródło } \\
\text { Source }\end{array}$ \\
\hline \multirow{3}{*}{ Xcfd81 } & $\begin{array}{c}\text { F: 5'TAT CCC CAA TCC CCT CTT3' } \\
\text { R: 5'GTC AAT TGT GGC TTG TCC CT3' }\end{array}$ & 283 & $\begin{array}{c}\text { Qiu i wsp. } \\
\text { Qiu et al. } \\
(2006)\end{array}$ \\
\hline \multirow{3}{*}{ STS $S_{-241}$} & F: 5'CTC ATT CTT GTT TTA CTT CCT TCA GT3' & & Yi i wsp. \\
& R: 5'GTC TCG TCT TCA GCA TCC TAT ACA3' & 241 & $\begin{array}{c}\text { Yi et al. } \\
(2008)\end{array}$ \\
\hline
\end{tabular}


Tabela 3. Interpretacja analiz - obecność genów $P m 2$ i $P m 4 b$ w badanych odmianach Table 3. Interpretation of analyses - presence of $P m 2$ and $P m 4 b$ genes in examined cultivars

\begin{tabular}{|c|c|c|c|c|}
\hline $\begin{array}{l}\text { Odmiana } \\
\text { Cultivar }\end{array}$ & $\begin{array}{l}\text { Zidentyfikowane geny } \\
\text { Identified genes }\end{array}$ & & $\begin{array}{l}\text { Odmiana } \\
\text { Cultivar }\end{array}$ & $\begin{array}{l}\text { Zidentyfikowane geny } \\
\text { Identified genes }\end{array}$ \\
\hline 1 Belissa & - & 24 & KWS Livius & $P m 4 b$ \\
\hline 2 Opcja & $P m 2, P m 4 b$ & 25 & KWS Ozon & - \\
\hline 3 Pokusa & Pm2 & 26 & Franz* & $P m 2, P m 4 b$ \\
\hline 4 Medalistka & $P m 4 b$ & 27 & Rivero & $P m 2, P m 4 b$ \\
\hline 5 Natula & $P m 4 b$ & 28 & Aleksander & $P m 4 b$ \\
\hline 6 Astoria & $P m 2, P m 4 b$ & 29 & Sailor* & $P m 2, P m 4 b$ \\
\hline 7 Arkadia & - & 30 & Florus & $P m 2, P m 4 b$ \\
\hline 8 Banderola & $P m 4 b$ & 31 & Lavantus & Pm2 \\
\hline 9 Hondia & $P m 2, P m 4 b$ & 32 & Leandrus & - \\
\hline 10 Jantarka & Pm2 & 33 & Platin & Pm2 \\
\hline 11 Mewa & Pm2 & 34 & Rotax & $P m 2, P m 4 b$ \\
\hline 12 Ostroga & $P m 2$ & 35 & Desamo & - \\
\hline 13 Tytanika & $P m 2, P m 4 b$ & 36 & Dolores & - \\
\hline 14 Memory & $P m 2, P m 4 b$ & 37 & Fakir & - \\
\hline 15 Bartosz & - & 38 & Delawar & - \\
\hline 16 Bonanza & $P m 4 b$ & 39 & Fidelius & $P m 2, P m 4 b$ \\
\hline 17 Janosch & $P m 2$ & 40 & Frisky & - \\
\hline 18 Tobak* & $P m 2, P m 4 b$ & 41 & LG Jutta & $P m 4 b$ \\
\hline 19 Artist & $P m 4 b$ & 42 & Linus & Pm2 \\
\hline 20 Patras* & $P m 2$ & 43 & Praktik & - \\
\hline 21 Julius & $P m 2, P m 4 b$ & 44 & RGT Kicker & Pm2 \\
\hline 22 KWS Dakotana & - & 45 & RGT Kilimanjaro & - \\
\hline 23 KWS Kiran & - & 46 & Hybery & - \\
\hline
\end{tabular}

*odmiany referencyjne, o potwierdzonej obecności genów odporności na mączniaka prawdziwego zbóż i traw (Bundessortenamt 2018) reference cultivars with confirmed presence of powdery mildew resistance genes (Bundessortenamt 2018)

siada kombinację tych dwóch genów. Wskazuje to na dużą powszechność tych genów w programach hodowlanych. Prace Lutz i wsp. (1992), Svec i wsp. (2002) oraz Alam i wsp. (2011) potwierdzają, że geny $P m 2, P m 4 b$ oraz kombinacja genów Pm2 + Pm6 są nadal jednymi z najczęściej występujących źródeł odporności pszenicy na mączniaka prawdziwego zbóż i traw w odmianach europejskich i polskich. Bardzo duże rozpowszechnienie tych genów sprawia, że zwiększa się wirulencja patogena wobec nich. Limpert i wsp. (1987) przeprowadzili badania dotyczące wirulencji B. graminis f. sp. tritici w Europie. Wyniki ich prac sprzed ponad 30 lat przedstawiają nieskuteczność pojedynczych genów Pm2 i $P m 4 b$. Według Felsenstein i Jaser (2007) w Niemczech wobec genu Pm2 wirulentnych jest 100\% izolatów patogena. Gen $P m 4 b$ również został sklasyfikowany jako niosący znikomą odporność. Z kolei Li i wsp. (2011) podaje, że gen Pm2 w wielu regionach świata nadal stanowi dobre źródło odporności. Pietrusińska i Czembor (2014) analizowali wirulencję izolatów sprawcy mączniaka prawdziwego w Polsce wobec odmian z ustalonymi genami odporności Pm. Zdecydowana większość (ponad 90\%) izolatów była wirulentna wobec genu $P m 2$. Gen $P m 4 b$ również nie wykazał dużej skuteczności - 74\% izolatów było zdolnych do porażenia odmiany z genem Pm4b. Z kolei według Ma i wsp. (2011), mimo iż gen Pm2 nie jest użyteczny jako główne źródło odporności, może utrzymywać skuteczność jako część piramidy genowej. W związku z obniżającą się efektywnością dotychczas szeroko wykorzystywanych genów odporności, konieczne jest dążenie do większego zróżnicowania genetycznego poprzez wprowadzanie w programach hodowlanych genów, które charakteryzują się wysoką skutecznością i które nie są powszechne w odmianach zarejestrowanych w Polsce. W tym celu, niezbędne jest poszukiwanie nowych źródeł odporności i kontynuacja badań dotyczących wirulencji B. graminis f. sp. tritici w Polsce i Europie.

W pracy dokonywano identyfikacji genów odporności z użyciem markerów molekularnych. Pszenica jest rośliną, 


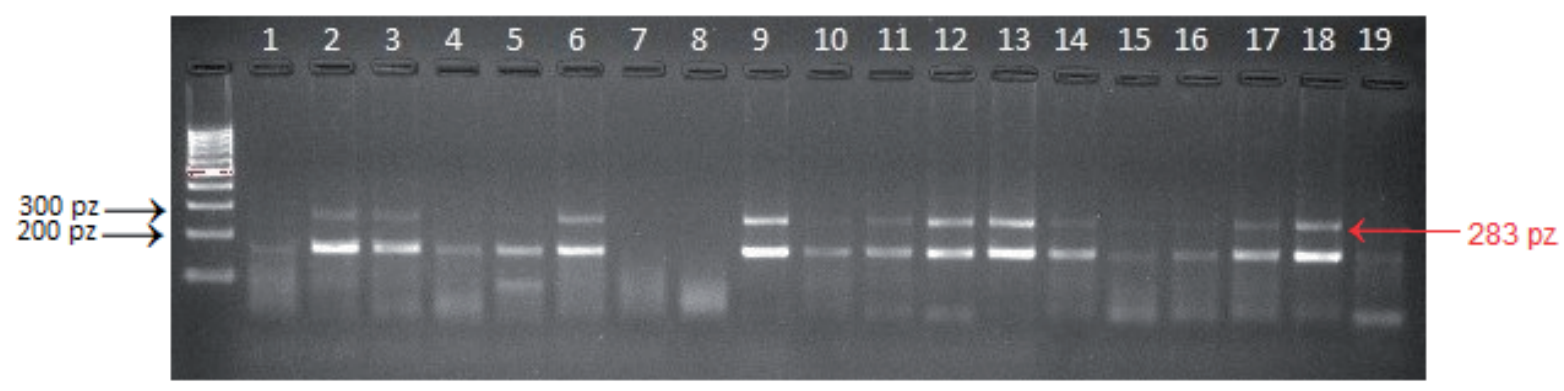

Rys. 1. Obraz elektroforetyczny z rozdziałem produktów PCR z użyciem markera Xcfd81. Kolejność genotypów na żelu została zamieszczona w tabeli 1.

Fig. 1. Electrophoresis of PCR products with marker Xcfd81. The order of genotypes in gel according to Table 1

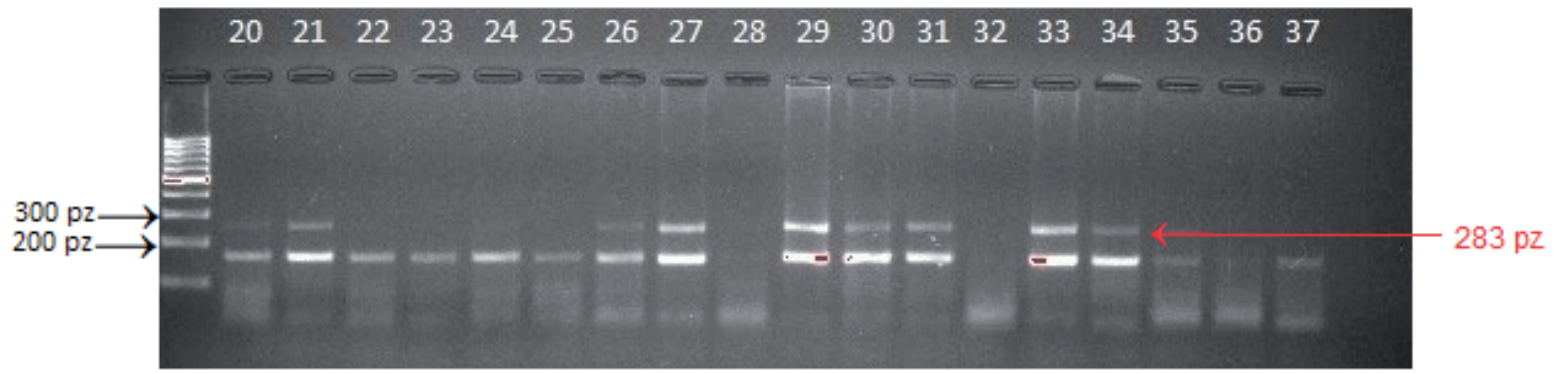

Rys. 2. Obraz elektroforetyczny z rozdziałem produktów PCR z użyciem markera Xcfd81. Kolejność genotypów na żelu została zamieszczona w tabeli 1.

Fig. 2. Electrophoresis of PCR products with marker Xcfd81. The order of genotypes in gel according to Table 1

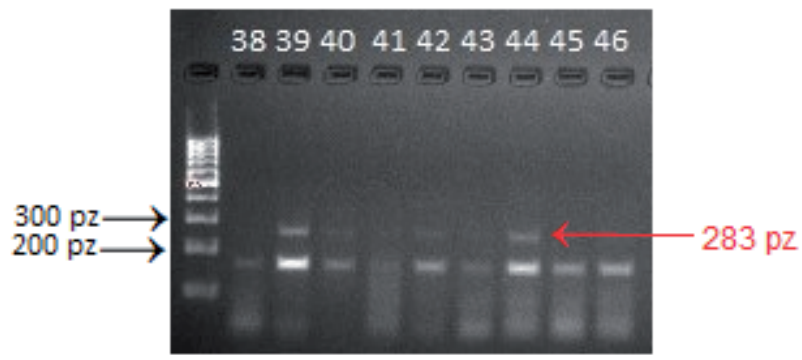

Rys. 3. Obraz elektroforetyczny z rozdziałem produktów PCR z użyciem markera Xcfd81. Kolejność genotypów na żelu została zamieszczona w tabeli 1

Fig. 3. Electrophoresis of PCR products with marker Xcfd81. The order of genotypes in gel according to Table 1

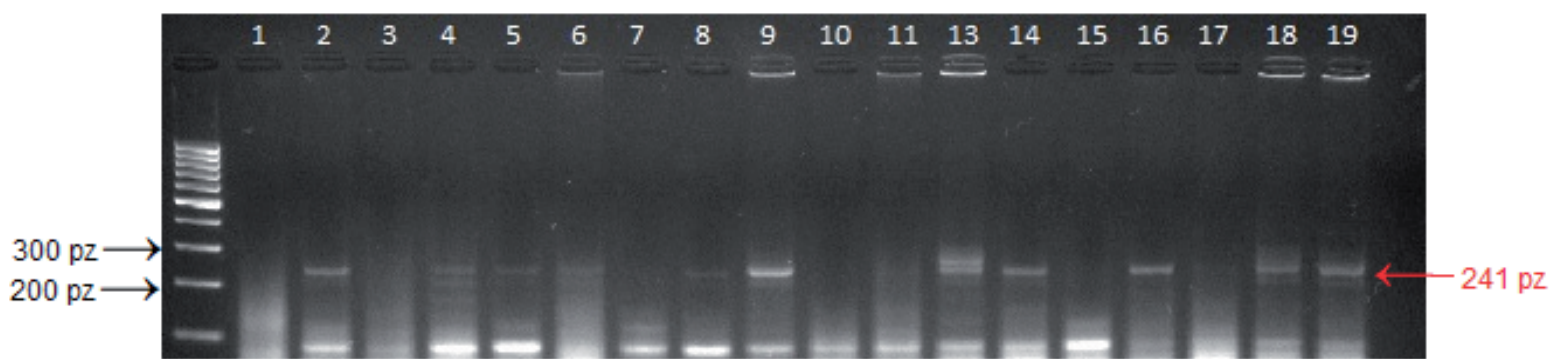

Rys. 4. Obraz elektroforetyczny z rozdziałem produktów PCR z użyciem markera $S T S_{-241}$. Kolejność genotypów na żelu została zamieszczona w tabeli 1 .

Fig. 4. Electrophoresis of PCR products with marker $S T S_{-241}$. The order of genotypes in gel according to Table 1 


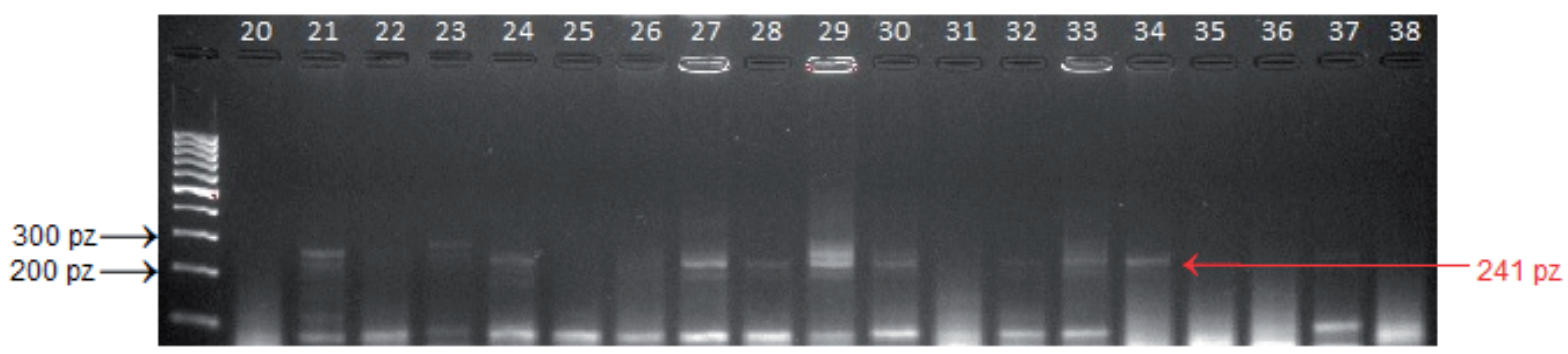

Rys. 5. Obraz elektroforetyczny z rozdziałem produktów PCR z użyciem markera $S T S_{-241}$. Kolejność genotypów na żelu została zamieszczona w tabeli 1.

Fig. 5. Electrophoresis of PCR products with marker $S T S_{-241}$. The order of genotypes in gel according to Table 1

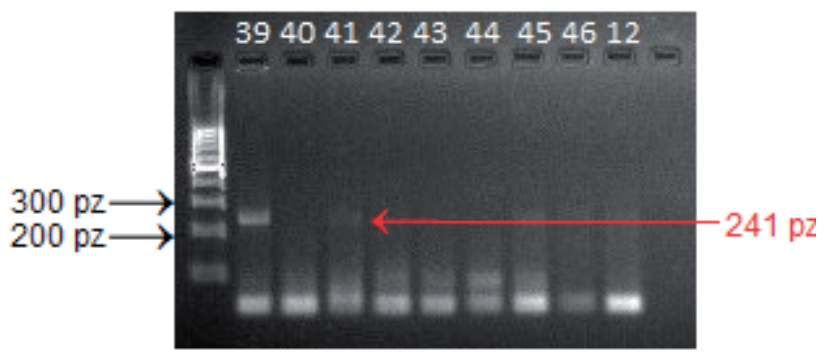

Rys. 6. Obraz elektroforetyczny z rozdziałem produktów PCR z użyciem markera $S T S_{-241}$. Kolejność genotypów na żelu została zamieszczona w tabeli 1.

Fig. 6. Electrophoresis of PCR products with marker $S T S_{-241}$. The order of genotypes in gel according to Table 1

dla której ze względu na jej duże znaczenie gospodarcze, prowadzi się wiele badań mających na celu stworzenie nowych markerów do identyfikacji genów odporności na mączniaka prawdziwego zbóż i traw, oraz badań oceniających przydatność konkretnych markerów w analizach (Gupta i Varshney 2000). Szczególnie w ostatnich latach dokonano dużego postępu w tych dziedzinach (Alam i wsp. 2011). Dużą zaletą MAS jest brak uzależnienia od warunków środowiskowych. W niniejszej pracy wykazano, że markery są bardzo użytecznym narzędziem identyfikacji genów. Ponadto, uzasadniona wydaje się być potrze- ba poszukiwania nowych, wysoce specyficznych markerów sprzężonych z genami odporności na mączniaka prawdziwego.

\section{Wnioski / Conclusions}

1. Wykazano przydatność markera $X c f d 81$ do identyfikacji genu Pm2.

2. Wykazano przydatność markera $S T S_{-241}$ do identyfikacji genu $P m 4 b$.

\section{Literatura / References}

Alam A., Xue F., Wang Ch., Ji W. 2011. Powdery mildew resistance genes in wheat: identification and genetic analysis. Journal of Molecural Biology Research 1 (1): 1-39. DOI: 10.5539/jmbr.v1n1p20.

Bennett F.G.A. 1984. Resistance to powdery mildew in wheat: a review of its use in agriculture and breeding programmes. Plant Pathology 33 (3): 279-300. DOI: 10.1111/j.1365-3059.1984.tb01324.x.

Bundessortenamt 2018. Beschreibende Sortenliste 2017. www.bundessortenamt.de/internet30/fileadmin/Files/PDF/bsl getreide 2017. pdf [dostęp: 11.05.2018].

COBORU 2018. http://www.coboru.pl [dostęp: 12.07.2018].

Czajowski G., Czembor P. 2016. Chorobotwórczość Blumeria graminis f. sp. tritici i Blumeria graminis f. sp. triticale sprawców mączniaka prawdziwego zbóż i traw na pszenicy i pszenżycie. [Pathogenicity of Blumeria graminis f. sp. tritici and Blumeria graminis f. sp. triticale the causal agents of wheat and triticale powdery mildew]. Progress in Plant Protection 56 (3): $360-365$. DOI: 10.14199/ppp-2016-058. 
Felsenstein F.G., Jaser B. 2007. Fungizidresistenz bei pilzlichen Getreide pathogenen und Wirksamkeit der vertikalen (qualitativen) Mehltauresistenz bei Weizen und Gerste. Situationsbericht 2005. www.epilogic.de/BL2007Bericht.pdf [dostęp: 6.06.2018].

Ge Y., Johnson J.W., Roberts J.J., Rajaram S. 1998. Temperature and resistance gene interactions in the expression of resistance to Blumeria graminis f. sp. tritici. Euphytica 99 (2): 103-109. DOI: 10.1023/A:1018392725474.

Gupta P.K., Varshney R.K. 2000. The development and use of microsatellite markers for genetic analysis and plant breeding with emphasis on bread wheat. Euphytica 113 (3): 163-185. DOI: 10.1023/A:1003910819967.

Hao Y., Parks R., Cowger C., Chen Z., Wang Y., Bland D., Johnson J., Murphy J.P., Guedira M., Brown-Guedira G. 2015. Molecular characterization of a new powdery mildew resistance gene Pm54 in soft red winter wheat. Theoretical and Applied Genetics 128 (3): 465-476. DOI: 10.1007/s00122-014-2445-1.

Huang J., Zhao Z., Song F., Wang X., Xu H., Huang Y., Diaoguo A., Li H. 2012. Molecular detection of a gene effective against powdery mildew in the wheat cultivar Liangxing 66. Molecular Breeding 30 (4): 1737-1745. DOI: 10.1007/s11032-012-9757-0.

Jasińska Z., Kotecki A. 2003 Szczegółowa uprawa roślin. Tom I. Wydawnictwo Akademii Rolniczej we Wrocławiu, 510 ss. ISBN 83-89189-15-1.

Kowalczyk K., Gruszecka D., Nowak M., Leśniowska-Nowak J. 2011. Resistance of Triticale hybrids with Pm4b and Pm6 genes to powdery mildew. Acta Biologica Cracoviensia - Series Botanica 53 (1): 57-62. DOI: 10.2478/v10182-011-0008-1.

Li H.J., Wang X.M., Song F.J., Wu C.P., Wu X.F., Zhang N., Zhou Y., Zhang X.Y. 2011. Response to powdery mildew and detection of resistance genes in wheat cultivars from China. Acta Agronomica Sinica 37 (6): 943-954. DOI: 10.1016/S1875-2780(11)60026-6.

Limpert E., Felsenstein F.G., Andrivon D. 1987. Analysis of virulence in populations of wheat powdery mildew in Europe. Journal of Phytopathology 120 (1): 1-8. DOI: 10.1111/j.1439-0434.1987.tb04408.x.

Lutz J., Limpert E., Bartoš P., Zeller F.J. 1992. Identification of powdery mildew resistance genes in common wheat (Triticum aeativum L.). I. Czechoslovakian Cultivars. Plant Breeding 108 (1): 33-39. DOI: 10.1111/j.1439-0523.1992.tb00097.x.

Ma H., Kong Z., Fu B., Li N., Zhang L., Jia H., Ma Z. 2011. Identification and mapping of a new powdery mildew resistance gene on chromosome 6D of common wheat. Theoretical and Applied Genetics 123 (7): 1099-1106. DOI: 10.1007/s00122-011-1651-3.

Ma P., Xu H., Li L., Zhang H., Han G., Xu Y., Fu X., Zhang X., An D. 2016. Characterization of a new Pm2 allele conferring powdery mildew resistance in the wheat germplasm Line FG-1. Frontiers in Plant Science 7 (546): 1-11. DOI: 10.3389/fpls.2016.00546.

Ma P., Xu H.X., Zhang H., Li L., Xu Y., Zhang X., An D. 2015. The gene PmWFJ is a new member of the complex Pm2 locus conferring unique powdery mildew resistance in wheat breeding line Wanfengjian 34. Molecular Breeding 35 (210): 1-9. DOI: 10.1007/s11032015-0403-5.

Miranda L.M., Murphy J.P., Marshall D., Leath S. 2006. Pm34: a new powdery mildew resistance gene transferred from Aegilops tauschii Coss. to common wheat (Triticum aestivum L.). Theoretical and Applied Genetics 113 (8): 1497-1504. DOI: 10.1007/s00122-0060397-9.

Mohan M., Nair S., Bhagwat A., Krishna T.G., Yano M., Bhatia C.R., Sasaki T. 1997. Genome mapping, molecular markers and markerassisted selection in crop plants. Molecular Breeding 3 (2): 87-103. DOI: 10.1023/A:1009651919792.

Niewoehner A.S., Leath S. 1998. Virulence of Blumeria graminis f. sp. tritici on winter wheat in the eastern United States. Plant Disease 82 (1): 64-68. DOI: 10.1094/PDIS.1998.82.1.64.

Pietrusińska A., Czembor J.H. 2014. Struktura wirulencji populacji Blumeria graminis f. sp. tritici występującej na terenie Polski w latach 2012-2013. [Virulence structure of the Blumeria graminis f. sp. tritici population occurring in Poland across 2012-2013]. Biuletyn Instytutu Hodowli i Aklimatyzacji Roślin 274: 15-25.

Pietrusińska A., Czembor J.H. 2015. Piramidyzacja genów - powszechne narzędzie używane w programach hodowlanych. [Gene pyramiding - a tool commonly used in breeding programs breeding programs]. Biuletyn Instytutu Hodowli i Aklimatyzacji Roślin 278: 3-16.

Qiu Y., Sun X., Zhou R., Kong X., Zhang S., Jia J. 2006. Identification of microsatellite markers linked to powdery mildew resistance gene Pm2 in wheat. Cereal Research Communications 34 (4): 1267-1273. DOI: 10.1556/CRC.34.2006.4.268.

Singrün C.H., Hsam S.L.K., Zeller F.J., Wenzel G., Mohler V. 2004. Localization of a novel recessive powdery mildew resistance gene from common wheat line RD30 in the terminal region of chromosome 7AL. Theoretical and Applied Genetics 109 (1): 210-214. DOI: 10.1007/s00122-004-1619-7.

Svec M., Szunics L., Miklovicova M., Slovakova T., Tisova V., Hauptvogel P. 2002. Identification of genes for resistance to wheat powdery mildew in Hungarian, Polish and Slovak wheat cultivars. Plant Protection Science 38 (2): 64-72.

Sztuba-Solińska J. 2005. Systemy markerów molekularnych i ich zastosowanie w hodowli roślin. [Molecular markers systems and their application in plant breeding]. Kosmos Problemy Nauk Biologicznych 54 (2-3): 227-239.

Tomkowiak A., Kurasiak-Popowska D., Grynia J., Nawracała J., Mikołajczyk S., Weigt D., Niemann J., Kiel A. 2017. Ocena przydatności markerów molekularnych Xgwm205, Xcfd81, Whs350 do identyfikacji genu odporności Pm2 na mączniaka prawdziwego zbóż i traw (Blumeria graminis f. sp. tritici) u odmian pszenicy o zróżnicowanym pochodzeniu. [Evaluation of the usefulness of molecular markers Xgwm205, Xcfd81, Whs350 for the identification of resistance gene Pm2 to powdery mildew (Blumeria graminis f. sp. tritici) in wheat cultivars of different origins]. Progress in Plant Protection 57 (2): 146-152. DOI: 10.14199/ppp-2017-023.

Tratwal A. 2012. Występowanie ważnych gospodarczo chorób pszenicy ozimej w Polsce w latach 2006-2010. [Occurence of more important diseases on winter wheat in Poland 2006-2010]. Annales Universitatis Mariae Curie-Skłodowska, Sectio E, Agricultura 67 (2): $29-41$.

Yi Y.J., Liu H.Y., Haung X.Q., An L.Z., Wang F., Wang X.L. 2008. Development of molecular markers linked to the wheat powdery mildew resistance gene Pm $4 b$ and marker validation for molecular breeding. Plant Breeding 127 (2): 116-120. DOI: 10.1111/j.14390523.2007.01443.x. 